\title{
Effect of salinity stress on growth, chemical constituents and stem anatomy of Duranta erecta L. plants
}

\author{
Nahed G. Abdel-Aziz', Azza A. Mazher'1, Mona H. Mahgub', Mona A. Darwish², Rania \\ M. A. Nassar ${ }^{3}$ and Ahmed S. Abdel-Aal ${ }^{1}$
}

${ }^{I}$ Department of Ornamental Plants and Woody Trees, National Research Center, Giza, Egypt

${ }^{2}$ Department of Ornamental Horticulture, Faculty of Agriculture, Cairo University, Giza, Egypt.

${ }^{3}$ Department of Agricultural Botany, Faculty of Agriculture, Cairo University, Giza, Egypt.

\author{
Received: 15 August 2020 / Accepted 10 Oct. 2020 / Publication date: 25 Oct. 2020
}

\begin{abstract}
The present study was carried out at the Ornamental Horticulture Department, Faculty of Agriculture, Cairo University, Giza, during the two successive seasons of 2014 and 2015 in order to enhance the growth of duranta plants grown under different concentrations of salinity $(2000,4000,8000$ and 12000 ppm of salt mixture, $\mathrm{NaCl}: \mathrm{CaCl} 2,1: 1 \mathrm{w} / \mathrm{w}$ ) by foliar application of 200 and $400 \mathrm{ppm}$ ascorbic acid. The results showed that, growing the plants under $2000 \mathrm{ppm}$ salinity $+200 \mathrm{ppm}$ ascorbic acid gave the highest values of number of branches, root length, fresh and dry weight of leaves, cl ( $a, b), \mathrm{N} \%, \mathrm{P} \%$ and $\mathrm{K} \%$ concentrations in both seasons. While, growing the plants under $4000 \mathrm{ppm}$ salinity $+200 \mathrm{ppm}$ ascorbic acid gave the highest value of plant height in both seasons. Data also reveal that the application of $400 \mathrm{ppm}$ ascorbic acid grown under stress of $8000 \mathrm{ppm}$ salinity caused enhancement in stem structure of salinized plants. Such treatment caused recovery more than $80 \%$ of the reduction occurred in all included tissues of the main stem where their meanvalues were almost reached the level of the control.
\end{abstract}

Keywords: Duranta erecta, Salinity, vegetative growth, chemical constituents and Anatomy

\section{Introduction}

Duranta erecta (Golden dewdrop) family Verbenaceae is a native of Mexico, Central America, South America to Argentina, southern Florida (possibly naturalized), Bermuda, the Bahamas, and the West Indies (Howard 1989; Liogier 1995; Little et al. 1974). The species is widely cultivated and escaped in the tropics and subtropics including Hawaii, American Samoa, and Guam (Pacific Islands Ecosystems at Risk 2002). Duranta erecta (Golden dewdrop) grows wild mostly in dry coastal areas (750 to $900 \mathrm{~mm}$ of annual precipitation in Puerto Rico) from near sea level to over $100 \mathrm{~m}$ in elevation (Little et al., 1974). It also grows in disturbed areas in moister habitat, especially along roads (Pacific Island Ecosystems at Risk 2002). Because it is moderately intolerant of shade and does not compete well with taller vegetation, golden dewdrop is usually found in rocky or sandy areas with low shrubs and sparse grass and herbs. Although it is more common on limestone, the shrub also grows in areas with igneous rocks. The species tolerates light to moderate salt spray. Duranta erecta (Golden dewdrop) forms a part of the coastal scrub community and contributes to soil and ecosystem stability. It is a popular ornamental used for accent plants and hedges in tropical and subtropical parts of the world because of its profuse displays of flowers and fruits (Floridata, 1999). Ethyl acetate and aqueous extracts of leaves showed significant antimalarial activity when administered to mice (Castro et al., 1996). In small quantities, fruits are used to treat intestinal worms (Whistler, 2000).

Salinity is one of the world's most serious environmental problems in agriculture. It is estimated that about one-third of the world's cultivated land is affected by salinity (PerezAlfocea et al., 1996). The National Academy of Sciences of the USA includes salinization of soils and waters as one of the leading processes contributing to a possible worldwide catastrophe (Francois and Maas, 1994). The increasing world population, especially in arid and semi-arid regions, food shortages, and land scarcity are compelling the use of lands not utilized because of salinity and other soil stresses. Salinity and sodality problems are characterized by an excess of inorganic salts and are common in the arid and semiarid lands (ASAL) where they have been naturally formed under the prevailing climatic conditions and due to the high rates of evapotranspiration and lack of leaching water (Mengel and Kirkby, 1982; Shannon et al., 1994). In the arid and semiarid parts of Africa, for instance, salinity and alkalinity are

Corresponding Author: Nahed G. Abdel-Aziz, Department of Ornamental Plants and Woody Trees, National Research Center, Giza, Egypt 
major problems affecting about $24 \%$ of the continent (Reich et al., 2004). Salinity of arable land is an increasing problem of many irrigated, arid and semi-arid areas of the world where rainfall is insufficient to leach salts from the root zone, and it is a significant factor in reducing crop productivity (Francois and Maas, 1994).

Vitamins are considered as the accessory nutrients, required in minute quantities. Most of the vitamins are involved in enzyme systems. Vitamin contents of plants are also known to show altered metabolism under the influence of salinity (Anjali and Aruna, 2013).

Ascorbic acid (vitamin C) is a familiar molecule because of its dietary significance, most aspects of its metabolism and some aspects of its function in plants are very poorly understood. For example, its biosynthetic pathway has not been firmly established even though it reaches mill molar concentrations in most tissues. Humans and some other animals (including other primates and guinea pigs) depend on ascorbate in their diet because of loss of a functional form of the last enzyme (1-gulono1,4-lactone oxidase) of the biosynthesis pathway. Ascorbate is best known for its function as an antioxidant and for its role in collagen synthesis. Collagen deficiency results in the symptoms of scurvy (Nicholas 1996). Ascorbic acid has effects on many physiological processes including the regulation of growth and metabolism of plants under saline conditions and increasing physiological availability of water and nutrient (Barakat, 2003). In addition, ascorbic acid protects metabolic processes against $\mathrm{H}_{2} \mathrm{O}_{2}$ and other toxic derivatives of oxygen affecting many enzyme activities, minimizes the damage caused by oxidative processes through synergistic function with other antioxidants and stabilize membranes (Shao et al., 2008).

\section{Materials and Methods}

This study was carried out at the Ornamental Horticulture Department, Faculty of Agriculture, Cairo University, Giza. during the two successive seasons 2014 and 2015 to investigate the effect of ascorbic acid under salinity stress conditions on growth and chemical constituents of Duranta erecta seedlings. The liberality work on ornamental and woody trees department - National Research Centre. Seedlings of Duranta erecta were obtained from (private farm) (six months old, $20 \mathrm{~cm}$ height) were used as a plant material. The experiment was under open field conditions through the two seasons. The seedlings of Duranta erecta were cultivated $(20 \mathrm{~cm}$ length) in the first week of March in both seasons, and transported in $30 \mathrm{~cm}$ pots during the second week of March 2014 and 2015. The soil use was a combine with sand and compost 2:1 (V: V). All agricultural operations procedure fertilized all plants with Kristalon (NPK 19:19:19), produced by Phayzon Company, Holland at the rate of $5 \mathrm{gm} /$ pot used in three times through the growth season; The plants were located under open field condition and irrigation was done according to the plants need. The physical and chemical analysis of these growing media presented in Table (1).

Table 1: Physical and chemical analysis of the growing media used in the experiment. A. Physical analysis.

\begin{tabular}{|c|c|c|c|c|c|c|c|c|c|}
\hline \multirow{2}{*}{\multicolumn{3}{|c|}{ Medium material }} & \multirow{2}{*}{\multicolumn{2}{|c|}{$\begin{array}{c}\text { SP } \\
\% \\
\end{array}$}} & \multicolumn{2}{|c|}{ F.C } & \multirow{2}{*}{\multicolumn{2}{|c|}{ W.P \% }} & \multirow[b]{2}{*}{ A.W \% } \\
\hline & & & & & 0.1 & 0.33 & & & \\
\hline \multirow{3}{*}{\multicolumn{3}{|c|}{$\begin{array}{l}\text { Virgin sandy sample } \\
\text { Mixed (sand + compost) sample } \\
\text { Compost sample }\end{array}$}} & & & 7.7 & 6.2 & \multicolumn{2}{|c|}{2.2} & 5.5 \\
\hline & & & & & 33.7 & 24.8 & \multicolumn{2}{|c|}{9.5} & 24.2 \\
\hline & & & & & 56.1 & 48.3 & \multicolumn{2}{|c|}{16.3} & 39.8 \\
\hline \multirow{2}{*}{$\begin{array}{c}\mathrm{EC} \\
(\mathrm{dS} / \mathrm{m})\end{array}$} & \multirow[t]{2}{*}{ PH } & & \multicolumn{3}{|c|}{ Ions (meq/L) } & & & & \\
\hline & & $\mathrm{Ca}++$ & Mg++ & $\mathrm{Na}+$ & $\mathbf{K}+$ & $\left(\mathrm{CO}_{3}--\right.$ & $\mathrm{O}_{3-}$ & Cl- & $\mathrm{SO}_{4}^{--}$ \\
\hline 0.54 & 7.65 & 0.5 & 1.4 & 3.5 & 0.5 & & & 0.6 & 3.2 \\
\hline
\end{tabular}

After three weeks from transplanting the plants received the first application of salinity treatments $(0,2000,4000,8000,12000$ ppm). Ascorbic acid Commercial vitamin, Ascorbic acid was used. The plants sprayed with ascorbic acid concentration at $(0,200,400 \mathrm{ppm})$ received the first application after two weeks from salinity and the second application after two weeks from the first application. The experiment was made in a randomized complete block design with15 treatments, each treatment included three replicates. The treatments as follows: 1 . Control, plants were irrigated with tap water. 2 . Four levels of salinity in irrigation water; namely, 2000, 4000, 8000 and $12000 \mathrm{ppm}$ of salt mixture 
(NaCl: $\mathrm{CaCl} 2,1: 1 \mathrm{w} / \mathrm{w}) .3$ Three levels of ascorbic acid were applied $(0,200$ and $400 \mathrm{ppm})$ on each of the tested four levels of salinity. The pots were located under open field conditions. Each level of salinity in irrigation water was added regularly $(750 \mathrm{ml} / \mathrm{pot} / \mathrm{week})$ during the whole period of the experiment (nine months from transplanting). Irrigation treatments were applied four times with salinized water followed by one irrigation with tap water (for leaching the accumulated salts) and then repeated in the same manner till the end of the experiment. In order to improve the growth of duranta plants grown under stress of salinity in irrigation water, ascorbic acid concentrations were sprayed twice. The first spray was done after one month from transplanting and the second one was applied two months from the first spray. Tween-20 was added as a spreading agent for tested treatments. The recorded data includes: 1. Plant height $(\mathrm{cm})$. 2. Number of leaves/ plant. 3. Root length $(\mathrm{cm})$. 4. Fresh and dry weight of leaves (g/plant). Meanwhile, fresh leaves (g/plant) were collected to determine photosynthetic pigments (chlorophyll a, b and carotenoids), according to Nornai (1982).Total carbohydrates \% were determined according to Dubois et al. (1956). Furthermore, leave samples were collected and were oven dried at $70^{\circ} \mathrm{C}$ for the determination of nitrogen according to Cottenie et al., (1982), phosphorus were determined according to Snell and Snell (1949) and potassium contents were determined according to Chapman and Pratt (1978).

\section{Statistical analysis:}

A randomize complete block design with two factor was used for analysis vegetative growth with three replications for each parameter. The treatment means were compared by least significant difference (L.S.D.) test as given by Snedecor and Cochran (1976) by used Assistat program.

\section{Results and Discussion}

\section{Vegetative growth:}

Data presented in Table (2) showed that the effect of saline water irrigation, ascorbic acid and their interaction on vegetative parameters of Doranta erecta plants. The results demonstrated clearly that the concentration of salinity at $12000 \mathrm{ppm}$ significantly decreased plant height, No. of leaves, root length, fresh and dry of leaves compared with control plants in both seasons. The decrements in the first season were $(21.60,33.81,10.13,63.28$ and $66.94 \%)$, respectively, and in the second season were $(22.0$, $27.86,11.72,64.11$ and $67.39 \%$ ), respectively, compared with control plants. These results are in agreement with those obtained by Arafa et al. (2009) on sorghum plant, Farahat, (2013) on Grevillea robusta plant, Amirjani, (2015) on periwinkle plants and Hashish et al. (2015) on gladiolus plants, they reported that application of saline water alone led to significant reduction in all growth parameters. The reduction in plant growth due to the effect of salinity on many metabolic processes including enzyme activity, the activity of the mitochondria and chloroplasts and protein synthesis, these attributed by Mengel and Kirkby (1982). Concerning the effect of ascorbic acid on vegetative parameters, data in Table (2) revealed that application of ascorbic acid at $200 \mathrm{ppm}$ had a significant favorable effect on plant height and number of leaves/plant in both seasons. The increments were (14.53\% and $10.24 \%)$ for plant height and $(27.32 \%$ and $34.30 \%)$ for number of leaves in the first and second seasons, respectively, compared with control plants. Increasing the concentrations of ascorbic acid from 200 to $400 \mathrm{ppm}$ led to an increase in root length, fresh and dry weight of leaves in both seasons. The increments were $(7.64 \%$ and $17.44 \%)$ for root length, $(25.98 \%$ and $24.47 \%)$ for fresh weight of leaves and $(32.56 \%$ and $30.34 \%$ ) for dry weight of leaves in both seasons, respectively, compared with control plants. These results are in agreement with those obtained by Abdel-Aziz et al. (2009) on gladiolus plants, Badran et al. (2013) on Khya sengalensis seedlings, Khafagy et al. (2013) on Hibiscus rosa-sinensis plants and Nikee et al. (2014) on Satureja hortensis L. plants, they found that application of ascorbic acid increased all plant parameters. The effect of ascorbic acid treatments may be due to the substantial role of ASc in many metabolic and physiological processes, these attributed to the postulation of Shaddad et al., 1990, and may be attributed to the biochemical functions of ascorbate which can be divided into four categories; enzyme cofactor, electron transport and antioxidant (Smirnoff, 1996).Regarding the effect of interaction between saline water irrigation and ascorbic acid application, data presented in Table (2) mentioned that the highest values of plant height were obtained when plants treated with ascorbic acid at $200 \mathrm{ppm}$ combined with non-saline water $(129.33$ and $139.67 \mathrm{~cm})$, respectively, in both season compared with other treatments. It is clear from data in the first and second seasons that the combined 
Middle East J. Agric. Res., 9(4): 711-720, 2020

Table 2: Effect of ascorbic acid on vegetative growth of Duranta erecta plants, aged 9 months, grown under salinity conditions in 2014 and 2015 seasons.

\begin{tabular}{|c|c|c|c|c|c|c|c|c|c|c|}
\hline \multirow[t]{2}{*}{ Treatments } & \multicolumn{2}{|c|}{$\begin{array}{l}\text { Plant height } \\
\text { (cm) }\end{array}$} & \multicolumn{2}{|c|}{$\begin{array}{l}\text { No. of } \\
\text { leaves }\end{array}$} & \multicolumn{2}{|c|}{$\begin{array}{l}\text { Root length } \\
\text { (cm) }\end{array}$} & \multicolumn{2}{|c|}{$\begin{array}{c}\text { F.W. of leaves } \\
\text { (g/plant) }\end{array}$} & \multicolumn{2}{|c|}{$\begin{array}{l}\text { D.W. of leaves } \\
\text { (g/plant) }\end{array}$} \\
\hline & 2014 & 2015 & 2014 & 2015 & 2014 & 2015 & 2014 & 2015 & 2014 & 2015 \\
\hline Control & 126.00 & 135.89 & 330.56 & 394.11 & 59.06 & 66.83 & 104.69 & 112.77 & 30.91 & 34.53 \\
\hline 2000ppm S. & 118.89 & 130.78 & 379.78 & 426.67 & 61.83 & 67.69 & 72.58 & 78.43 & 20.97 & 23.64 \\
\hline 4000ppm S. & 110.67 & 121.94 & 281.56 & 352.11 & 54.11 & 64.03 & 69.19 & 72.98 & 19.50 & 21.98 \\
\hline 8000ppm S. & 108.22 & 118.24 & 255.44 & 302.89 & 53.08 & 63.61 & 49.60 & 54.91 & 13.25 & 15.55 \\
\hline 12000 ppmS. & 98.78 & 106.00 & 218.78 & 248.33 & 53.56 & 59.00 & 38.44 & 40.47 & 10.22 & 11.26 \\
\hline L.S.D. at 5\% & 3.29 & 3.71 & 14.89 & 21.98 & 2.54 & 2.65 & 4.76 & 4.90 & 2.27 & 2.47 \\
\hline Control & 103.27 & 115.57 & 252.13 & 284.93 & 54.06 & 58.53 & 58.24 & 62.29 & 16.00 & 18.03 \\
\hline 400ppm AS. & 116.00 & 124.75 & 306.53 & 366.87 & 58.19 & 68.74 & 73.37 & 77.53 & 21.21 & 23.50 \\
\hline L.S.D. at 5\% & 2.55 & 2.87 & 11.53 & 17.03 & 1.96 & 2.05 & 3.68 & 3.79 & 1.76 & 1.91 \\
\hline Control & 121.33 & 134.67 & 299.00 & 372.00 & 57.17 & 67.00 & 73.25 & 75.35 & 20.72 & 22.45 \\
\hline 2000ppm S. & 117.00 & 128.00 & 302.67 & 301.00 & 57.83 & 58.67 & 67.79 & 73.61 & 18.98 & 21.79 \\
\hline 4000ppm S. & 85.67 & 102.50 & 263.00 & 313.67 & 53.83 & 47.47 & 64.87 & 69.98 & 17.97 & 20.29 \\
\hline 8000ppm S. & 104.33 & 115.67 & 246.00 & 279.33 & 51.47 & 60.33 & 44.65 & 50.45 & 11.74 & 14.13 \\
\hline 12000ppm S. & 88.00 & 97.00 & 150.00 & 158.67 & 50.00 & 59.17 & 40.65 & 42.08 & 10.57 & 11.49 \\
\hline 200ppm AS. & 129.33 & 139.67 & 349.33 & 403.67 & 57.67 & 65.50 & 116.15 & 130.83 & 34.61 & 40.16 \\
\hline $2000+200 p p m$ AS. & 120.00 & 130.67 & 424.33 & 513.67 & 63.00 & 70.67 & 73.84 & 79.42 & 21.48 & 24.06 \\
\hline $8000+200$ ppm AS. & 112.33 & 122.33 & 269.00 & 314.33 & 53.50 & 63.17 & 49.73 & 54.35 & 13.32 & 15.33 \\
\hline $12000+200$ ppm AS. & 105.67 & 111.00 & 263.33 & 294.00 & 54.83 & 58.50 & 36.66 & 39.01 & 9.71 & 10.81 \\
\hline 400ppm AS. & 127.33 & 133.39 & 343.33 & 406.67 & 62.33 & 68.00 & 124.68 & 132.15 & 37.40 & 40.97 \\
\hline $2000+400 \mathrm{ppm}$ AS. & 119.67 & 133.67 & 412.33 & 465.33 & 64.67 & 73.73 & 76.10 & 82.26 & 22.45 & 25.08 \\
\hline $4000+400 \mathrm{ppm}$ AS. & 122.33 & 130.00 & 282.67 & 355.00 & 53.83 & 75.30 & 73.62 & 72.99 & 21.13 & 22.77 \\
\hline 8000+400ppm AS. & 108.00 & 116.73 & 251.33 & 315.00 & 54.27 & 67.33 & 54.42 & 59.94 & 14.69 & 17.20 \\
\hline $12000+400$ ppm AS. & 102.67 & 110.00 & 243.00 & 292.33 & 55.83 & 59.33 & 38.03 & 40.32 & 10.38 & 11.49 \\
\hline L.S.D. at 5\% & 5.71 & 6.43 & 25.79 & 38.09 & 4.40 & 4.59 & 8.25 & 8.48 & 3.93 & 4.27 \\
\hline
\end{tabular}


effect between salinity level at $2000 \mathrm{ppm}$ and ascorbic acid at $200 \mathrm{ppm}$ significantly increased number of leaves (424.33 and 513.67), respectively, compared with other treatments. The combined effect between ascorbic acid at $400 \mathrm{ppm}$ and salinity at $2000 \mathrm{ppm}$ in the first season, and combined with salinity at $4000 \mathrm{ppm}$ in the second season significantly increased root length compared with other treatments. Date in the same Table showed that the combination effect between ascorbic acid at 400 ppm with non- saline water treatment led to increase fresh and dry weight of leaves in the first season (124.68 and $37.40 \mathrm{gm} / \mathrm{plant}$ ) and in the second season (132.15 and $40.97 \mathrm{gm} / \mathrm{plant}$ ), respectively, compared with other treatments.

\section{Chemical constituents}

\subsection{Pigments content}

Data demonstrated in Table (3) showed the response of pigments content of Duranta erecta leaves to the salinity levels and foliar application of ascorbic acid concentration. In both seasons, the $0 \mathrm{ppm}$ salinity treatment caused the highest values of chlorophyll (a), (b) and (carotenoids), and these contents were decreased gradually with increasing the level of salinity to reach the minimum values with the application of $12000 \mathrm{ppm}$ salinity. These results are in agreement with the finding of Farahat et al. (2013) on Grevillea robusta plants, Ibrahem et al. (2013) on Khaya sengalensis, Sayed et al. (2014) on Tagetes erecta and Nisha (2015) on Dalbergia sissoo, they found that pigment contents(chlorophyll a, $\mathrm{b}$ and carotenoids) were decreased with increasing salinity levels.

Results obtained concerning the chlorophyll (a), (b) and (carotenoids) contents in response to foliar application of ascorbic acid treatment revealed that, in both seasons, pigments content were relatively higher in plants sprayed with $400 \mathrm{ppm}$ ascorbic acid. While, reducing the concentration of ascorbic acid to $200 \mathrm{ppm}$ gave lower value of pigments content in the first and second seasons, compared with high concentration treatment. Mosleh et al. (2014) on Prunus armeniaca L. Results indicated that total chlorophyll content in the apricot leaves significantly increased by increasing the application of ascorbic acid at both seasons. Also, Abdel-Aziz et al., 2006 on Khaya sengalensis plants, Abdel-Aziz et al., (2007) on Syngonium podphyllum L. plants, Mohamed and Mohamed (2015), on (Helianthus annuus var. Sakha 53), Hira et al., (2016) on Cucumis sativus plant and Samin et al., (2016), they showed that the plants grown under foliar application of ascorbic acid showed significant increase in total chlorophyll, compared to untreated plants. These increments in photosynethic pigments contents may be attributed to increase in photosynethic process efficiency, which led to increase net assimilation of $\mathrm{Co}_{2}$ which is known as the basic unit of carbohydrate. The data obtained showed that in the first season, the combination between salinity at $0 \mathrm{ppm}+$ foliar application of ascorbic acid at $400 \mathrm{ppm}$ increased the chlorophyll (a), (b) and (carotenoids) content (0.70, 0.37 and $0.36 \mathrm{mg} / \mathrm{gm}$. F.W.), respectively. While, in the second season, decreasing the concentration of ascorbic acid to $200 \mathrm{ppm}$ gave the highest values of $\mathrm{Chl}(\mathrm{a})$ and (b) content combined with the non-saline water treatments $((0.85$ and $0.44 \mathrm{mg} / \mathrm{gm}$. F.W.), respectively, although the combination between the non-saline water treatment plus foliar application of ascorbic acid at $4004200 \mathrm{ppm}$ in the second season, there were a gradual increase in the carotenoids content $(0.47 \mathrm{mg} / \mathrm{gm}$. F.W. $)$, followed by salinity at $2000 \mathrm{ppm}$ plus ascorbic acid at $400 \mathrm{ppm}(0.33$ and $0.45 \mathrm{mg} / \mathrm{gm}$. F.W. $)$, respectively, in the first and second seasons.

\subsection{Carbohydrates (\%)}

Data on the effect of different salinity levels and various ascorbic acid foliar applications on total carbohydrates percentages of Duranta erecta in leaves are presented in Table (3). It is clear from data that non-saline water treatment increased the total carbohydrates percentage in both seasons (32.82 and $36.75 \%$ ), respectively, in the first and second seasons, compared with salinity treatments. On the other hand, raising the level of salinity markedly decreased the total carbohydrates percentage from 8000 and $12000 \mathrm{ppm}$ giving (27.47 and 27.70\%) in the first season, and (32.37 and 24.65\%) in the second season. The present findings are generally in accordance with those reported by Eid et al.,(2011) on Tagetserecta, Mazher et al., (2012) on Chrysanthemum indicum and Farahat et al., (2013) on Gerevillae robusta plant, they found that, the highest concentrations of salinity decreased total carbohydrates. It is also clear from the data that spraying duranta plants with ascorbic acid treatments resulted highest value of percentage of total carbohydrates $(31.24 \%)$ when plants treated with ascorbic acid at $400 \mathrm{ppm}$ in the first season, and $200 \mathrm{ppm}$ in the second season which giving (33.65\%).These results are agreement with Khafagy et al., (2013) on Hibiscus rosa-sinensis, Samin et al., (2016) on Solanum 
melongena, they found that ascorbic acid at different concentrations caused significant increases in total carbohydrates contents in leaves as compared with untreated plants. According to the data, it is clearly noticed that the maximum total carbohydrates percentage was recorded with plants untreated with salinity at $0 \mathrm{ppm}+$ ascorbic acid at $400 \mathrm{ppm}$ giving $(34.18 \%)$ in the first season. Whereas, in the second season, salinity at $2000 \mathrm{ppm}+$ ascorbic acid at $400 \mathrm{ppm}$ gave the highest values of total carbohydrates percentage $(38.31 \%)$.

Table 3: Effect of ascorbic acid on pigment content (mg/g F.W.) and total carbohydrates (\%) of Duranta erecta plants, aged 9 months grown under salinity conditions in the two seasons 2014 and 2015.

\begin{tabular}{lcccccccc}
\hline \multirow{2}{*}{ Treatments } & \multicolumn{3}{c}{ Pigments content } & \multicolumn{3}{c}{$\begin{array}{c}\text { Pigments content } \\
\text { mg/g F.W. }\end{array}$} & \multicolumn{2}{c}{ Total carbohydrates } \\
& \multicolumn{3}{c}{ mg/g F.W. } & \multicolumn{3}{c}{ 2015 } & $\mathbf{2 0 1 4}$ & $\mathbf{2 0 1 5}$ \\
\cline { 2 - 8 } & Chl. a & Chl.b & carotenoids & Chl.a & Chl.b & Carotenoids & & \\
\hline Control & 0.68 & 0.32 & 0.33 & 0.82 & 0.39 & 0.41 & 32.82 & 36.75 \\
2000ppm S. & 0.65 & 0.27 & 0.31 & 0.73 & 0.35 & 0.38 & 29.82 & 34.57 \\
4000ppmS. & 0.60 & 0.26 & 0.30 & 0.70 & 0.35 & 0.36 & 28.01 & 32.60 \\
8000ppmS. & 0.54 & 0.23 & 0.29 & 0.64 & 0.33 & 0.35 & 27.47 & 32.37 \\
12000ppmS. & 0.46 & 0.21 & 0.23 & 0.57 & 0.28 & 0.27 & 27.70 & 24.65 \\
Control & 0.54 & 0.23 & 0.26 & 0.63 & 0.30 & 0.28 & 27.10 & 30.24 \\
200ppmAS. & 0.59 & 0.26 & 0.30 & 0.71 & 0.35 & 0.37 & 28.78 & 33.65 \\
400ppmAS. & 0.63 & 0.28 & 0.31 & 0.74 & 0.37 & 0.40 & 31.24 & 32.68 \\
Control & 0.65 & 0.28 & 0.30 & 0.79 & 0.32 & 0.32 & 30.84 & 35.43 \\
2000ppmS. & 0.60 & 0.24 & 0.29 & 0.65 & 0.33 & 0.30 & 2791 & 30.20 \\
4000ppmS. & 0.53 & 0.23 & 0.28 & 0.62 & 0.32 & 0.27 & 26.19 & 30.80 \\
8000ppmS. & 0.45 & 0.20 & 0.23 & 0.54 & 0.30 & 0.28 & 23.01 & 31.16 \\
12000ppmS. & 0.45 & 0.18 & 0.21 & 0.53 & 0.23 & 0.24 & 27.51 & 23.59 \\
200ppmAS. & 0.69 & 0.32 & 0.32 & 0.85 & 0.44 & 0.44 & 33.44 & 37.38 \\
2000+200AS. & 0.66 & 0.26 & 0.31 & 0.76 & 0.34 & 0.40 & 28.46 & 35.19 \\
4000+200AS. & 0.59 & 0.26 & 0.30 & 0.71 & 0.35 & 0.40 & 26.98 & 31.56 \\
8000+200AS. & 0.55 & 0.25 & 0.32 & 0.67 & 0.33 & 0.37 & 27.60 & 36.62 \\
12000+200AS $>$ & 0.45 & 0.22 & 0.25 & 0.57 & 0.29 & 0.26 & 27.44 & 27.48 \\
400ppmAS. & 0.70 & 0.37 & 0.36 & 0.82 & 0.41 & 0.47 & 34.18 & 37.44 \\
2000+400AS. & 0.68 & 0.30 & 0.33 & 0.79 & 0.38 & 0.45 & 31.24 & 38.31 \\
4000+400AS. & 0.67 & 0.29 & 0.32 & 0.77 & 0.37 & 0.41 & 30.85 & 35.45 \\
8000+400AS. & 0.63 & 0.23 & 0.32 & 0.70 & 0.36 & 0.39 & 31.80 & 29.34 \\
12000+400AS. & 0.47 & 0.23 & 0.22 & 0.60 & 0.31 & 0.30 & 28.15 & 22.88 \\
\hline
\end{tabular}

\subsection{Mineral content in leaves ( $N, P$ and $K \%)$}

Data of (N, P and K) percentage in the leaves of Duranta erecta plants as affected by different levels of salinity and various concentrations of ascorbic acid in both seasons are presented in Table (4). As regards the effect of salinity levels, it is clear from data in Table (4) that salinity at $2000 \mathrm{ppm}$ increased (N, P and K\% D.W.) in the leaves by $(1.23,0.19$ and $0.80 \%$ D.W.) in the first season, while, in the second season by( $1.30,0.20$ and $0.85 \%$ D.W.), respectively. Whereas, the lowest values of mineral content in Duranta erecta leaves when plants treated with salinity at $12000 \mathrm{ppm}$ in both seasons.

Farahat et al., (2013) on Grevillea robusta plant and Ibrahem et al., (2013) on Khaya sengalensis, they found that $\mathrm{N}, \mathrm{P}$ and $\mathrm{K} \%$ were decreased with increasing the salinity levels. Concerning the effect of ascorbic acid on (N and P\%D.W.) in leaves, it was increased by (1.16 and $0.17 \%$ D.W.) in the first season, and by $(1.23$ and $0.18 \%$ D.W. $)$ in the second season, respectively, in response to foliar application at $400 \mathrm{ppm}$, followed by application of $200 \mathrm{ppm}$ which led to increase $(\mathrm{K} \%)$ by $(0.74$ and $0.80 \%$ D.W.) in the first and second seasons, respectively. These results are agreement with Eid et al., (2011) on Tagetes erecta L., Badran et al., (2013) on Khaya senegalinsis plant and Nisha 2015 on Dalbergia sissoo plants, they showed that ascorbic acid improved content of N, P and $\mathrm{K} \%$ in leaves.

The data also showed the interaction between salinity levels and ascorbic acid application, it can be noticed that salinity at $2000 \mathrm{ppm}$ combined with foliar application of ascorbic acid at $400 \mathrm{ppm}$ gave the highest percentage of ( $\mathrm{N}$ and $\mathrm{P} \%)$ were $(1.29$ and $0.20 \%$ D.W. $)$, in the first season, while in the second season by $(1.35$ and $0.22 \%$ D.W.), respectively. The plants were treated with salinity at 2000 
ppm combined with $200 \mathrm{ppm}$ ascorbic acid gave the highest value of ( $\mathrm{K} \%)$ in both seasons were $(0.84$ and $0.89 \%$ D.W.), respectively.

Table 4: Effect of ascorbic acid on N, P and K \% of Duranta erecta plants, aged 9 months grown under salinity conditions in the two seasons 2014 and 2015.

\begin{tabular}{lcccccc}
\hline & \multirow{6}{*}{ Characters } & \multicolumn{7}{c}{ Mineral of content in leaves } \\
\cline { 2 - 7 } Treatments & $\mathbf{5 \%}$ & $\mathbf{2 0 1 4}$ & & & $\mathbf{2 0 1 5}$ & \\
\cline { 2 - 7 } & & $\mathbf{N \%}$ & $\mathbf{K \%}$ & $\mathbf{N \%}$ & $\mathbf{P \%}$ & K\% \\
\hline Control & 1.13 & 0.18 & 0.73 & 1.26 & 0.17 & 0.80 \\
2000ppmS. & 1.23 & 0.19 & 0.80 & 1.30 & 0.20 & 0.85 \\
4000ppmS. & 1.10 & 0.16 & 0.68 & 1.18 & 0.18 & 0.72 \\
8000ppmS. & 0.99 & 0.15 & 0.65 & 1.11 & 0.16 & 0.70 \\
12000ppmS. & 0.87 & 0.13 & 0.63 & 1.04 & 0.14 & 0.65 \\
Control & 0.92 & 0.15 & 0.66 & 1.11 & 0.16 & 0.67 \\
200ppmAS. & 1.10 & 0.16 & 0.74 & 1.21 & 0.17 & 0.80 \\
400ppmAS. & 1.16 & 0.17 & 0.69 & 1.23 & 0.18 & 0.76 \\
Control & 1.04 & 0.17 & 0.73 & 1.19 & 0.15 & 0.72 \\
2000ppmS. & 1.14 & 0.18 & 0.82 & 1.24 & 0.19 & 0.80 \\
4000ppmS. & 1.05 & 0.14 & 0.60 & 1.11 & 0.17 & 0.64 \\
8000ppmS. & 0.88 & 0.16 & 0.58 & 1.09 & 0.16 & 0.62 \\
12000ppmS. & 0.53 & 0.11 & 0.60 & 0.92 & 0.13 & 0.59 \\
200ppmAS. & 1.15 & 0.18 & 0.75 & 1.29 & 0.17 & 0.90 \\
2000+200AS. & 1.26 & 0.19 & 0.84 & 1.32 & 0.19 & 0.89 \\
4000+200AS. & 1.10 & 0.16 & 0.78 & 1.24 & 0.18 & 0.82 \\
8000+200AS. & 1.02 & 0.15 & 0.70 & 1.10 & 0.16 & 0.68 \\
12000+200AS. & 1.01 & 0.13 & 0.65 & 1.09 & 0.14 & 0.71 \\
400ppmAS. & 1.22 & 0.19 & 0.71 & 1.32 & 0.19 & 0.77 \\
2000+400AS. & 1.29 & 0.20 & 0.74 & 1.35 & 0.22 & 0.86 \\
4000+400AS. & 1.17 & 0.17 & 0.66 & 1.21 & 0.18 & 0.70 \\
8000+400AS. & 1.07 & 0.15 & 0.67 & 1.15 & 0.15 & 0.80 \\
12000+400AS. & 1.08 & 0.15 & 0.65 & 1.12 & 0.14 & 0.66 \\
\hline
\end{tabular}

\section{Anatomical studies}

\subsection{Stem anatomy}

Microscopica measurements of certain histological characters in transverse sections through the median portion of the main stem of normal Duranta erecta plants and of those grown under salinity stress of $8000 \mathrm{ppm}$ as well as of those salinized by $8000 \mathrm{ppm}$ and affected by foliar spray with $400 \mathrm{ppm}$ ascorbic acid are presented in Table (5). Likewise, microphotographs illustrating these treatments are shown in Figure (1). It obvious from Table (5) and Figure (1) that the salinity level of $8000 \mathrm{ppm}$ reduced the diameter of the main stem by $35.8 \%$ less than the control. The decrease in stem diameter, due to salinity stress, could be attributed mainly to the prominent decrease in all included tissues except that of pith diameter which showed prominent increase of $28.6 \%$ over the control. It is clear that salinity stress decreased the thickness of periderm, cortex, phloem tissue and xylem tissue as well as mean diameter of vessel by 23.3, 16.1, 39.9, 58.2 and 5.3\% less than those of the control; respectively. The present findings are generally in accordance with those reported by Reda et al. (2000) and by Nassar et al. (2016) on Leucaena as well as by Reda (2007) on coffee senna. Data also reveal that the application of $400 \mathrm{ppm}$ ascorbic acid on Duranta erecta plants grown under stress of $8000 \mathrm{ppm}$ salinity caused enhancement in stem structure of salinized plants. Such treatment caused recovery more than $80 \%$ of the reduction occurred in all included tissues of the main stem where their mean values were almost reached the level of the control. Thus, it could be stated that ascorbic acid had the ability to minimize the harmful effect of salinity on anatomical structure of Duranta erecta stem. Such treatment induced small decrease in stem diameter of salinized plant by $16.1 \%$ below the control due to decrements in thickness of all included tissues in spite of negligible increase of 3.1\% in mean diameter of vessel over the control. Thickness of periderm, cortex, phloem tissue, xylem tissue and diameter of pith were decreased by $9.9,11.3,10.5,18.2$ and $14.2 \%$ less than those of the control; respectively. Worthy to note that the mean values of all tissues in stems of salinized plants which were sprayed with ascorbic acid, except that of pith diameter, were decidedly higher over those of salinized plants. The main stem 
diameter was increased by $30.7 \%$ over stem diameter of salinized plant due to increments in most of included tissues by $17.4,5.7,49.1$ and $95.7 \%$ for thickness of periderm, cortex, phloem tissue and xylem tissue; respectively. As far as the author is aware, information about the effect of foliar spray with ascorbic acid on the anatomical structure of the main stem of duranta plants, grown under salinity stress are not available.

Table 5: Measurements in micrometers $(\mathrm{Mm})$ of some histological characters in cross sections through the median portion of the main stem, at the age of five months from transplanting, of normal Duranta erecta plants and those grown under stress of $8000 \mathrm{ppm}$ salinity as well as of those salinized and affected by foliar spray with $400 \mathrm{ppm}$ ascorbic acid (Means of three sections from three different specimens)

\begin{tabular}{|c|c|c|c|c|c|c|}
\hline \multicolumn{2}{|l|}{ Treatments } & \multicolumn{5}{|c|}{ 8000ppm } \\
\hline $\begin{array}{l}\text { Histological } \\
\text { characters }\end{array}$ & Control & $\begin{array}{l}\text { 8000ppm } \\
\text { salinity }\end{array}$ & $\begin{array}{l} \pm \% \text { to } \\
\text { control }\end{array}$ & $\begin{array}{c}400 \mathrm{ppm} \\
\text { Salinity }+ \\
\text { Ascorbic acid }\end{array}$ & $\begin{array}{l} \pm \% \text { to } \\
\text { control }\end{array}$ & $\begin{array}{c} \pm \% \text { to } \\
\text { 8000ppm } \\
\text { salinity }\end{array}$ \\
\hline Stem diameter & 3839.5 & 2463.7 & -35.8 & 3220.9 & -16.1 & +30.7 \\
\hline Thickness of periderm & 63.6 & 48.8 & -23.3 & 57.3 & -9.9 & +17.4 \\
\hline Thickness of cortex & 106.2 & 89.1 & -16.1 & 94.2 & -11.3 & +5.7 \\
\hline Thickness of phloem tissue & 211.8 & 127.2 & -39.9 & 189.6 & -10.5 & +49.1 \\
\hline Thickness of xylem tissue & 1165.9 & 487.5 & -58.2 & 954.2 & -18.2 & +95.7 \\
\hline Mean diameter of vessel & 22.6 & 21.4 & -5.3 & 23.3 & +3.1 & +8.9 \\
\hline Diameter of pith & 742.2 & 954.8 & +28.6 & 636.5 & -14.2 & -33.3 \\
\hline
\end{tabular}

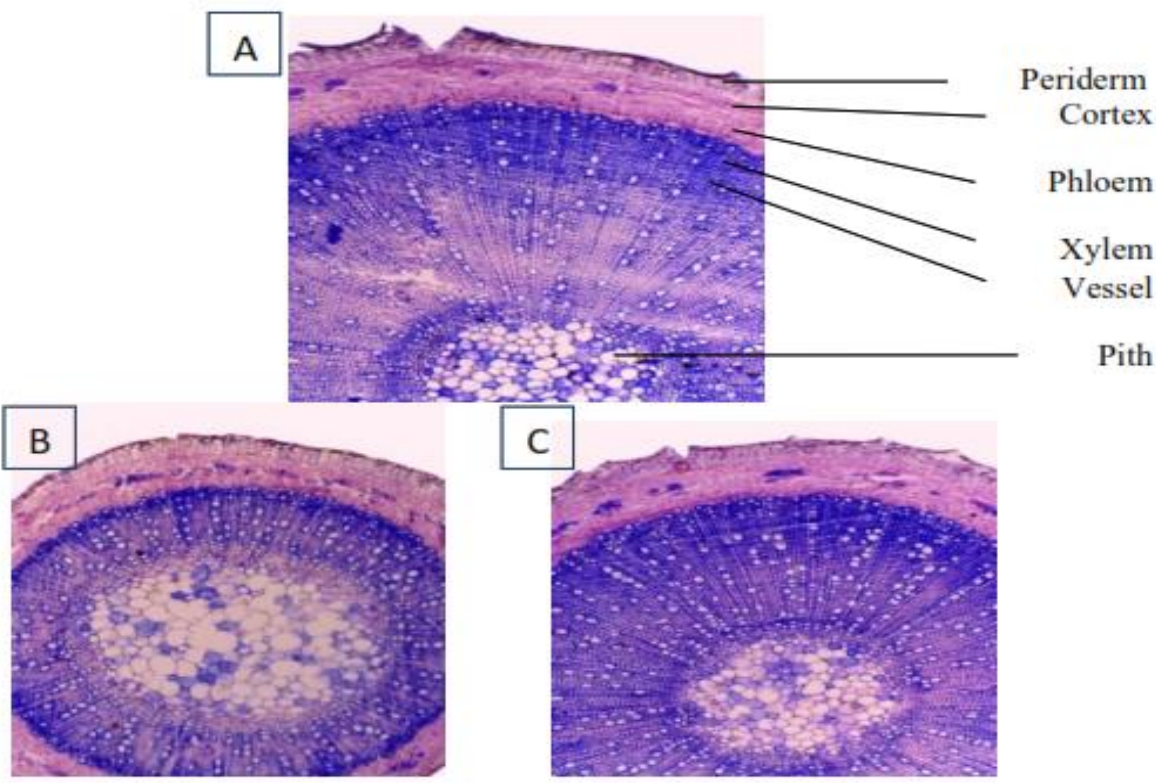

Fig. 1: Transverse sections through the median portion of the main stem of Duranta erecta plants, at the age of five months from transplanting, as affected by salinity stress and sprayed with ascorbic acid. (X 60).

A- From untreated plant (control).

B- From plant grown under salinity stress of $8000 \mathrm{ppm}$.

C- From plant grown under salinity stress of $8000 \mathrm{ppm}$ and sprayed with $400 \mathrm{ppm}$ ascorbic acid.

\section{References}

Abdel-Aziz, Nahed G., El-Quesni, E.M. Fatma and M.M. Farahat, 2007. Response of vegetative growth and some chemical constituents of Syngonium podophyllum L. to foliar application of thiamine, ascorbic acid and kinetin at nubaria. World Journal of Agricultural Sciences 3(3):301-305. 
Abdel Aziz, Nahed G., Taha, S. Lobna and M.M. Ibrahim, Soad, 2009. Some studies on the effect of putrescine, ascorbic acid and thiamine on growth, flowering and some chemical constituents of gladiolus plant at nubaria. Ozean J. of App. Sci., 2(2); 169-179.

Abdel-Aziz, Nahed G., Mazher, A.M. Azza and E. EL-Habba, 2006. Effect of foliar spraying with ascorbic acid on growth and chemical constituents of Khaya senegalensis grown under salt condition. American -Eurasian J. Agric. \& Environ. Sci. 1(3): 207-214.

Amirjani, M.R., 2015. Effect of salinity stress on seed germination and antioxidative defense system of Catharanthus roseus. Arpn Journal of Agricultural and Biological Science, (10)5: 163-171.

Anjali, R. and R. Aruna, 2013.Effect of Nacl salinity on B-carotene, thiamine, riboflavin and ascorbic acid contents in the leaves of Amaranthus Polygamous L. var. pusakirti. Oct. J Env. Res., 1(3): 211-216.

Arafa, A.A., Khafagy, A.M., and F.M. El-Banna, 2009.The effect of glycinebetaine or ascorbic acid on grain germination and leaf structure of sorghum plants grown under salinity stress. Australian Journal of Crop Science 3(5):294-304.

Badran, F., M. Abdou, E. Ahmed, R. Taha and S. Ibrahim, 2013. The role of ascorbic and salicylic acids in modifying the growth and chemical composition of salt stress Ed Khaya senegalensis seedlings. J. Plant Production, Mansoura Univ., 4 (12): 1739 - 1750.

Barakat, H., 2003. Interactive effects of salinity and certain vitamins on gene expression and cell division. Int. J. of Agri. and Biol., 5(3): 219-225.

Castro, O., M. Barrios, M. Chinchilla, and O. Guerrero. 1996. Chemical and biological evaluation of the effects of plant extracts against Plasmodium berghei. Revista de Biologia Tropical, 44(2A): 361-367.

Chapman, H.D. and P.F. Pratt, 1978. Methods of analysis for soil, plant and water. Agric. Sci. Dept., Univ. California, USA 309. Chem., 36: 345-347.

Cottenie, A.M., M. Verloo, L. Kiekens, G. Velghe, and R. Camerlynck,1982. Chemical Analysis of Plant and Soil.Laboratory of Analytical and Agrochemistry. State Univ. Ghent, Belgium, 100129.

Dubois, M., F. Smith, K.A. Gilles, J.K. Hammilton, and P.A. Robers, 1956.Colormeteric methods to determination of sugars and related substances. Anal. Chem., 28(3): 350-356.

Eid, Rawia, A. Taha, S. Lobna and Ibrahiem, M.M. Soad, 2011. Alleviation of Adverse Effects of Salinity on Growth, and Chemical Constituents of Marigold Plants by Using Glutathione and Ascorbate. J. of Appl. Sci. Res., 7(5): 714-721.

Farahat, M.M., Azza, A.M., Mona, H. and Sahar, M., 2013. Salt tolerance in Grevillea robusta seedlings via foliar application of ascorbic acid. Middle-East J. of Sci. Res., 14(1): 09-15.

Floridata,.1999. Duranta erecta. http:// floridata.com/ref.d.dra_ere.cfm. 3 p.

Francois, L.E., and E.V. Maas, 1994. Crop response and management on salt affected soils. In : M. Pessarakli (ed), Handbook of plant and Crop stress. Marcel Dekker, Inc., New York, USA, 149181.

Hashish, Kh. I., Rawia A. Eid, Magda M. Kandil and Azza A.M. Mazher, 2015. Study on Various Level of Salinity on Some Morphological and Chemical composition of gladiolus Plants by Foliar Spray with Glutathione and Thiamine. Inter. J. of Chem.Tech.Res., 8 (9): 334-341.

Hira, N.,Nudrat, Aisha A. and A. Muhamad, 2016. Impact of ascorbic acid on growth and some physiological attributes of cucumber (Cucumis sativus) plants under water-deficit condition. Pak. J. Bot., 48(3): 877-883.

Howard, R.A., 1989. Flora of the Lesser Antilles. Vol. 6. Arnold Arboretum, Harvard University, Jamaica Plain, MA.658. http://www.nrcs.usda.gov/technical/worldsoils/papers/desertificationafrica.html

Ibrahem, E.H., Nahed G. Abd El Aziz, Sami A.M. and Azza A.M. Mazhar, 2013. Response of Growth and Chemical Constituents in Khaya sengalensis to Salinity and Gypsum under Calcareous Soil Conditions. World Applied Sciences Journal, 22 (4): 447-452.

Khafagy, M.A., M.Y.A. Abdalla, H.A.A. Hussein, and Sara, A.M., 2013.Response of Hibiscus rosasinensis L. to the interactive effect of seawater salinity and ascorbic acid. J. Plant Production, Mansoura Univ., 4(1):51-78.

Liogier, H.A., 1995. Descriptive flora of Puerto Rico and adjacent islands. Vol. 4. Editorial de la Universidad de Puerto Rico, San Juan, PR. 617. 
Little, E.L., Jr., R.O. Woodbury, and F.H. Wadsworth, 1974. Trees of Puerto Rico and the Virgin Islands. Vol. 2.Agriculture Handbook 449.U.S. Department of Agriculture, Washington, DC.1, 024.

Azza, A.M. Mazhar, Shaymaa I. Shedeed, Nahed G. Abdel-Aziz, and Mona H. Mahgoub, 2012. Growth flowering and chemical constituents of chrysanthemum indicum L. plant in response to different levels of humic acid and salinity. J. of Appl. Sic. Res. 8(7): 3697-3706.

Mengel, K. and E.A. Kirkby, 1982. Principles of plant nutrition, $3^{\text {rd }}$ edition, International Potash Institute, Bern, Switzerland, pp. 228-235.

Mohamed, A.A. and A.I. Mohamed, 2015. Effect of Indole butyric, Arginine, Cyanocobalamine (B12), Ascorbic acid and their interactions on growth, yield and some metabolic constituents of sunflower plants. Int. J. Adv. Res. Biol. Sci,. 2(12): 154-162.

Mosleh M.S. Duhoky, Jassim M.A. Al-Aa'reji and F.H. Kh. Ghazi, 2014.Effect of Sheep Manure, Ascorbic Acid and Sulphur On Some Growth Characteristics of Apricot (Prunus armeniacaL.) cv. Royal. J. of Res. in Agric. and Animal Sci., $2 \sim$ Issue 8 pp: 06-18.

Nassar, Rania M.A., Shanan, Nermeen T. and Reda, Faten M., 2016. Active yeast extract counteracts the harmful effects of salinity stress on the growth of leucaena plant. Scienta Hort., 201: 61-67.

Nicholas, S., 1996.The Function and Metabolism of Ascorbic Acid in Plants. Annals of Botany 78: 661-669.

Nikee, Elham, P. Alireza, and Z. Hossein, 2014. Influences of ascorbic acid and gibberellin on alleviation of salt stress in summer savory (Satureja hortensis L.). Inter. J of Biosci. vol. 5(4): 245-255.

Nisha., 2015. Effect of salinity on morphophysiological characteristics of Dalbergia sissoo Roxb. Thesis submitted to CCSHAU Hisar.

Nornai, R., 1982. Formula for determination of chlorophyllus pigments extracted with N, N-dimethyl formamide. Plant Physiol., 69:1376-1381.

Pacific Island Ecosystems at Risk. 2002. Durantaerecta L., Verbenaceae. http://www.hear. org/pier3/duere.htm. 2.

Perez-Alfocea, F., M.E. Balibrea, A. Santa Cruz and M.T. Estan, 1996. Agronomical and physiological characterization of salinity tolerance in a commercial tomato hybrid. Plant and Soil 180, 251-257.

Reda, Faten M., 2007. Morphological, anatomical and physiological studies on Senna occidentalis L. Link plants grown under stress of different levels of salinity in irrigation water. J. Agric. Sci. Mansoura Univ., 32(10): 8301-8314.

Reda, Faten M., S.L. Maximous, and O.S.M. El-Kobisy, 2000. Morphological and anatomical studies on leucaena (Leucaena leucocephala) plants grown under stress of different levels of salinity in irrigation water. Bull. Fac. Agric. Cairo Univ., 51(3): 309-330.

Reich, P.F., S.T. Numbem, R.A. Almaraz, and H. Eswaran, 2004. Land resource stresses and desertification in Africa.

Samin J., H. Muhammad, W. Sher, B. Asmat, G. Humalra, and R. Fazli, 2016. Foliar application of ascorbic acid mitigates sodium chlorid induced stress in eggplant (Solanum melongena L.). Pak. J. Bot., 48(3): 869-876.

Sayyed, A., H. Gul, Z. Ullah, and M. Hamayun, 2014. Effect of salt stress on growth of Tagetes erecta L. Pakhtunkhwa J. Life Sci., (02): $96-106$.

Shaddad, M.A., A.F. Radi, A.M. Abdel-Rahman, M.M. Azooz, 1990. Response of seeds of Lupinus termis and Vicia faba to the interactive effect of salinity and ascorbic acid or pyridoxine. Plant and Soil J., 3: 122-177.

Shannon, M.C., C.M. Grieve, and L.E. Francoi, 1994. Whole plant response to salinity. In : R.E. Wilkinson (ed.). Plant environment Interactions. Marcel Dekker, New York, 199-244.

Smirnoff, N., 1996 Ascorbate metabolism in relation to oxidative stress. Biochem. Soc. Trans., 24: 472478.

Snedecor G.A. and W.G. Cochran, 1976. Statistical Method. Iowa State Univ. Press, Ames.

Snell F.D. and C.T. Snell, 1949.Colorimetric Methods of Analysis. $3^{\text {rd }}$ ed. Van Nostrand, New York, USA, 785-807.

Whistler, W.A., 2000.Tropical ornamentals, a guide. Timber Press, Inc., Portland, OR. 542. 